\title{
ANALISIS KINERJA KUALITAS PELAYANAN TERHADAP KEPUASAN MAHASISWA PADA SEKOLAH TINGGI TEKNOLOGI MUTU MUHAMMADIYAH (STTM M) DI TANGERANG
}

\author{
Suryo Sulistyo*, Asrori Mukhtarom** \\ soeryotyo@gmail.com,asrorimukhtarom84@gmail.com \\ *Dosen Sekolah Tinggi Teknologi Mutu Muhammadiyah, Tangerang \\ **Dosen Program Pascasarjana Universitas Muhammadiyah Tangerang
}

\begin{abstract}
This research aims to identify service quality performance to collegestudents, the method used is a surveys customer satisfaction by using random sampling techniqueand Cartesian diagrams byusing SPSS application. The survey was conducted on 235 collegestudents out of a total of 335 collegestudents. Surveys data were analyzed using Cartesian diagramsto identify services and levels of college student satisfaction to the quality of campus services. The results of the study show, in the quadrant I; F2 the appearance of lecturers and employees in the ordinate $(5,65,5,80), F 3$ the comfort and cleanliness of the lecture hall in the ordinate (5.56, 5,77), F9 Post Graduate education for lecturers and competencies in science in ordinates $(5,40,5,83), F 10$ the lecturer delivered an interactive and interesting talk in ordinates (4,92, 5,83), F13 Lecturers are willing to prepare teaching materials in the ordinate $(5,65,5,87)$, F14 lecturer support for student success in the ordinate $(5,65,5,87)$, shows that students are satisfied and considered important to students. In the quadrant II; F1 LCD, AC and WIFI facilities in the ordinate (4,56, 5,82), F7 Lecturers on time give talks in the ordinate (4,72, 5,75), F12 Study Program Card will be distributed according to the time specified in the ordinate $(4,71,5,56), F 15$ friendly administrative staff in the ordinate $(4,77$, 5,72), means it is unsatisfactory and is considered important for college student, In order to satisfy the student, it must be transferred to the quadrant I. Therefore the factors that are in quadrant II must be improved
\end{abstract}

Keywords:Quality, Service, STTM M

\section{A. PENDAHULUAN}

Kepuasan dan ketidakpuasan pelanggan (mahasiswa) dengan mutu pelayanan dalam proses pembelajaran memiliki keterkaitan yang kuat. Semakin berkualitas mutu pelayanan maka semakin tinggi pula pencapaian kepuasan mahasiswa, untuk itulah maka satu lembaga pendidikan khususnya pendidikan tinggi harus memperhatikan kualitas pelayanan terhadap mahasiswanya, karena hal ini sangat berguna untuk meningkatkan daya saing lembaga pendidikannya. Dengan mengetahui perilaku konsumen (mahasiswa) terhadap pelayanan yang mereka rasakan, sangat membantu suatu lembaga pendidikan dalam menentukan positioning strategy di antara para pesaingnya, apalagi kebutuhan konsumen yang terus meningkat dan didasari oleh tingkat kekritisan yang semakin tinggi cenderung menuntut pelayanan secara pribadi dan ikut dilibatkan dalam pengembangan suatu produk, untuk itulah maka satu lembaga pendidikan harus mampu memenuhi kebutuhan dan keinginan konsumen serta berusaha memenuhi apa yang mereka harapkan dengan cara yang lebih memuaskan daripada yang dilakukan para pesaing. 
Menurut Lupiyoadi dan Hamdani (2009:180) mendefinisikan "Cara pandang konsumen sering kali mengarah pada nilai lebih dari produk dan kinerja pelayanan yang diterimanya, serta membandingkannya dengan produk lain. Ini merupakan sebuah jawaban mengapa konsumen menjatuhkan pilihannya".

Mahasiswa aktif merupakan pengguna jasa layanan akademik dan administratif dalam lingkungan pendidikan tinggi, maka sebagai tolak ukur untuk menilai kualitas pelayanan yang diberikan dan upaya untuk meningkatkan kualitas pelayanan kepada mahasiswa adalah dengan cara melakukan pengukuran tingkat kepuasan mahasiswa sebagai pengguna, karena kinerja kualitas pelayanan suatu lembaga pendidikan khususnya dapat dianalisis melalui kepuasan mahasiswa atas faktor-faktor kepuasan pelayanan yang melekat pada proses akademik yang akan dirasakan oleh mahasiswa, hal inilah yang menjadi dasar pemikiran untuk tetap memenuhi kebutuhan, keinginan dan harapan pengguna dalam segala perubahan, sehingga kulitas pelayanan terhadap kepuasan mahasiswa mengalami perbaikan yang terus-menerus, untuk itulah diperlukan sistem manajemen mutu yang merupakan serangkaian arah, kebijakan, dan pengaturan kegiatan dalam pengelolaan organisasi, mulai dari perencanaan, pelaksanaan, dan pengendaliannya yang terintegrasi dalam rangka mencapai tingkat mutu tertentu yaitu kepuasan pelanggan (mahasiswa).

Salah satu indikator yang cukup handal untuk kelangsungan hidup suatu proses organisasi adalah kepuasan yang berkelanjutan. Peningkatan kelangsungan hubungan dengan pelanggan lama terus mengakuisisi pelanggan baru dengan konsep kepuasan pelanggan akan mempunyai pengaruh yang lebih besar terhadap bagian pasar (market share). Potensi permasalahan pelayanan akademik terhadap mahasiswa bisa ditemui pada setiap sistem, di mana kepuasan mahasiswa sebagai pengguna memiliki peran dalam keberhasilan pelayanan akademik yang berkualitas, fasilitas yang seharusnya dikategorikan sebagai fasilitas yang gagal memberikan kenyamanan dan kemudahan kepada mahasiswa tetapi ternyata lolos dari pemeriksaan kualitas, sehingga berakhir kepada mahasiswa sebagai pengguna, untuk itulah maka perlu ada kegiatan deteksi yang dilakukan di seluruh bagian, sehingga pelayanan yang buruk tidak sampai pada tahapan implementasi.

Gambaran umum pelayanan di STTM M, meliputi 5 dimensi kualitas jasa dalam proses penyampaian jasa pada konsumen yaitu (1) Bukti Fisik (tangible), yaitu fasilitas fisik, perlengkapan, pegawai dan sarana komunikasi; (2) keandalan (reliability), yaitu kemampuan memberikan pelayanan yang dijanjikan dengan segera, akurat dan memuaskan; (3) daya tanggap (responsiveness), yaitu berkaitan dengan kesediaan dan kemampuan para karyawan untuk membantu para pelanggan dan merespon permintaan mereka, serta menginformasikan waktu jasa diberikan, kemudian memberikan jasa secara cepat. (4) jaminan (assurance), mencakup pengetahuan, kemampuan, kesopanan, dan sifat dapat dipercaya yang dimiliki para karyawan, bebas dari bahaya, resiko atau keragu-raguan dan (5) empati (empathy), meliputi kemudahan dalam melakukan hubungan, komunikasi yang baik, perhatian pribadi, dan memahami masalah para pelanggan dan bertindak demi kepentingan pelanggan serta memberikan perhatian personal kepada para pelanggan.

Sebagaimana kaidah yang digunakan dalam mengembangkan penilaian dan instrumen akreditasi diantaranya yaitu, penilaian akreditasi diarahkan pada capaian kinerja tridharma perguruan tinggi (outcome-based accreditation), peningkatan daya saing, dan wawasan internasional (international outlook)Outcome-based 
accreditationyang dimaksud di sini adalah ketercapaian visi, misi, dan tujuan perguruan tinggi, untuk itu maka perlu dilakukan pembinaan dan upaya secara bertahap dan terus menerus agar peringkat akreditasi pada setiap perguruan tinggi lebih baik dari sebelumnya. Perguruan tinggi yang tidak adaptif terhadap perubahan yang ada, akan tergilas oleh perubahan itu sendiri, sehingga jumlah mahasiswa maupun dosen pada perguruan tinggi/program studi tersebut secara alamiah akan mengalami penurunan.

Untuk memenuhi persyaratan penelitian, kami sajikan jumlah keseluruhan (jumlah populasi) mahasiswa program studi teknik industri yang bisa dilihat dalam bentuk tabel dan diagram batang seperti tampak pada pada tabel 1.1.dan gambar 1.1, sedangkan untuk pencapaian target penerimaan mahasiswa baru program studi teknik industry periode tahun 2014 sampai 2019 yangtersaji dalam bentuk tabel dan diagram batang seperti tampak pada tabel 1.2. dan gambar 1.1.

Tabel 1.1.

Populasi Mahasiswa Program Studi Teknik Industri

Tahun Ajaran 2019/2020

\begin{tabular}{ccc}
\hline No & Semester & Populasi \\
\hline 1 & I & 0 \\
\hline 2 & II & 56 \\
\hline 3 & III & 40 \\
\hline 4 & IV & 55 \\
\hline 5 & V & 25 \\
\hline 6 & VI & 79 \\
\hline 7 & VII & 0 \\
\hline 8 & VIII & 80 \\
\hline Jumlah Populasi & 335 \\
\hline
\end{tabular}

\section{Gambar 1.1 \\ Populasi Mahasiswa Program Studi Teknik Industri}

TA. 2019/2020

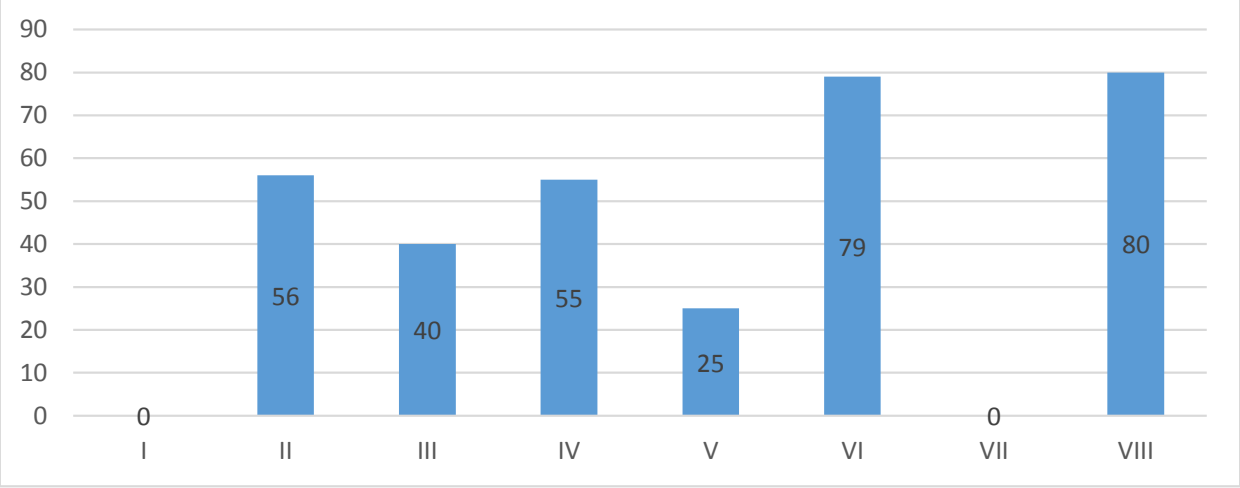


Tabel 1.2.

Pencapaian Target Penerimaan Mahasiswa Baru Program Studi Teknik Industri Tahun 2014 Sampai Tahun 2019.

\begin{tabular}{cccc}
\hline No & Tahun & Target & Pencapaian \\
\hline 1 & 2014 & 200 & 76 \\
\hline 2 & 2015 & 200 & 94 \\
\hline 3 & 2016 & 200 & 131 \\
\hline 4 & 2017 & 200 & 110 \\
\hline 5 & 2018 & 200 & 109 \\
\hline 6 & 2019 & 200 & 92 \\
\hline \hline
\end{tabular}

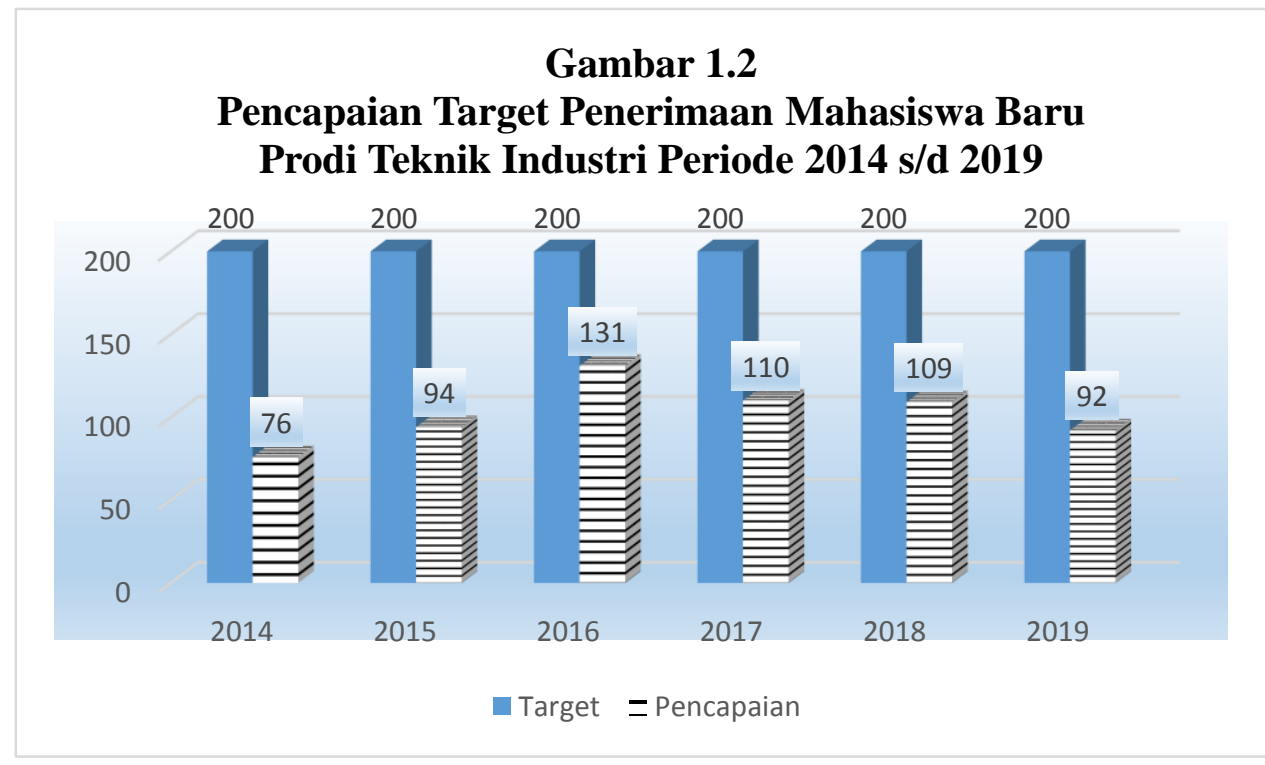

Dari hasil pengumpulan data yang terekam pada dokumen Tata Usaha STTM M menunjukan bahwa selama periode 2014 sampai 2019 jumlah pencapaian target untuk penerimaan mahasiswa baru tidak pernah tercapai,untuk itulah maka diperlukan analisis kinerja pelayanan terhadap kepuasan mahasiswa pada lembaga pendidikan STTM M khususnya program studi teknik industri.

Penelitian dilakukan terhadap mahasiswa aktif program studi teknik industri dengan menggunakan metode survei kepuasan mahasiswaterhadap kualitas pelayanan kampus melalui angket yang dibagikan kepada semua mahasiswa.Adapun tujuan dari penelitian ini adalah untuk mengetahui kinerja kualitas pelayanan terhadap kepuasan mahasiswa untuk kemudian melakukan perbaikan terhadap faktor-faktor yang kurang atau tidak memberikan kepuasan untuk kemudian dilakukan perbaikan.

Mengingat jumlah Perguruan Tinggi di Tangerang cukup banyak dan untuk mendapatkan hasil penelitian yang memadai, maka penelitian hanya difokuskan di Sekolah Tinggi Teknologi Mutu Muhammadiyah dan dikhususkan 
pada kinerja dari kualitas pelayaanan (service quality) yang diberikan oleh lembaga pendidikan STTM M terhadap mahasiswa program studi teknik industri sebagai pengguna dan dalam penelitian ini permasalahan yang akan dianalisis adalah bagaimanakah kepuasan mahasiswa terhadap kinerja pelayanan dan proses akademik di Sekolah Tinggi Teknologi Mutu Muhammadiyah?

\section{B. METODOLOGI PENELITIAN}

\section{Penentuan Institusi}

Penelitian dilakukan di lembaga pendidikan Sekolah Tinggi Teknologi Mutu Muhmmadiyah (STTM M) Tangerang, dengan pertimbangan sebagai berikut;

a. Lembaga pendidikan merupakan organisasi yang bergerak di bidang jasa, yang sangat diminati masyarakat;

b. Pada lembaga pendidikan STTM M untuk program studi Teknik Industri khususnya, mutu(quality) menjadi icon sekaligus sebagai prioritas utama;

c. Lembaga STTM Mmempunyai visi "Menjadi Perguruan Teknik Yang Unggul Berdasarkan Nilai-Nilai Islam", Hal ini merupakan dasar untuk mengetahui kinerja kualitas pelayanan terhadap kepuasan pelanggan;

d. Lembaga pendidikan tentunya lebih dekat dengan konsumen yang dalam hal ini adalah mahasiswa, sehingga lebih mudah untuk mengetahui keinginan dan harapan, sehingga untuk memenuhinya dapat lebih mudah dilakukan, dengan demikian kepuasan mahasiswa sebagai pengguna dapat dicapai.

\section{Metode Penentuan Sample}

Teknik sampling yang digunakan dalam penelitian ini adalah teknik random sampling, yaitu teknik pengambilan sampel di mana semua mahasiswa aktif program studi teknik industridalam populasi diberi kesempatan yang sama untuk dipilih menjadi anggota sampel, dengan pengambilan data dilakukan dengan metode survei dengan menggunakan kuesioner secara tertulis yang dibagikan langsung kepada responden, waktu yang digunakan untuk menyebar kuesioner sampai dengan kuesioner terkumpul 4 minggu yaitu mulai tanggal 15 Desember 2019 sampai dengan 15 Januari 2020, sampel yang berhasil terkumpul sejumlah 235 responden, dapat dilihat pada tabel 2.1.

Tabel 2.1.

Jumlah Sampel Yang Terkumpul

\begin{tabular}{lcc}
\hline \multicolumn{3}{c}{ Jumlah Sampel } \\
\hline \multicolumn{1}{c}{ Keterangan } & Jumlah & Persentase \\
\hline Kuisioner yang dibagikan & 335 & $100 \%$ \\
\hline Kuisioner Yang Tidak Kembali & 100 & $30 \%$ \\
\hline Kuisioner Yang Diolah & 235 & $70 \%$ \\
\hline
\end{tabular}

Berdasarkan data di atas, kuisioner yang dibagikan kepada responden sejumlah 335 responden, sedangkan kuisioner yang tidak dikembalikan sejumlah 100 responden dengan tingkat persentase $30 \%$, oleh karena itu kuisioner yang dapat diolah sebanyak 235 dengan tingkat persentase $70 \%$, hal ini dianggap telah representatif.

\section{Metode Pengumpulan Data}

Data yang digunakan dalam penelitian ini adalah data yang berupa skor jawaban responden atas 
penyebaran kuesioner yang meliputi; keinginan, kebutuhan dan harapan mahasiswa yang berkenaan dengan fasilitas fisik, keandalan atau kemampuan kampusdalam memuaskan mahasiswa, ketepatan dan kecermatan dalam pelayanan, jaminan dan kemudahan dalam melakukan hubungan, komunikasi, perhatian dan kenyamanan yang diberikan kampus pada mahasiswa, serta realita yang dirasakan oleh mahasiswa. Juga data yang diperoleh dari dokumen yang tersimpan di staf administrasi kampus, studi pustaka, buku-buku literatur, serta laporan penelitian yang berkaitan dengan permasalahan dalam penelitian ini.

\section{Definisi Operasional dan Pengukuran Variabel}

\section{a. Kualitas pelayanan}

Kualitas pelayanan merupakan keunggulan-keunggulan atas pelayanan yang diberikan kepada mahasiswa dengan tujuan mampu memenuhi harapan mahasiswa.

Kualitas pelayanan dinilai dengan menggunakan skor antara 1 sampai dengan 6 , yang meliputi: Harapan yaitu tingkat kepentingan pelayanan menurut mahasiswa sebagai konsumen yang diberikan oleh institusi. Realitas yaitu tingkat kepuasan mahasiswa terhadap pelayanan yang diberikan oleh institusi.

Kualitas pelayanan yang diberikan oleh lembaga pendidikan tinggi kepada mahasiswa tampak pada tabel 2.2.

Tabel 2.2.

Faktor Kualitas Pelayanan Dan Skor

\begin{tabular}{|c|c|c|}
\hline Faktor & Faktor Kepuasan & Skor \\
\hline 1 & LCD, AC dan WIFI berfungsi dengan baik & $\begin{array}{l}6=\text { sangat penting, } 5=\text { penting, } 4=\text { cukup penting, } \\
3=\text { kurang penting, } 2=\text { tidak penting, } 1=\text { sangat tidak } \\
\text { penting. }\end{array}$ \\
\hline 2 & $\begin{array}{l}\text { Dosen dan karyawan berpenampilan baik dan } \\
\text { rapih }\end{array}$ & $\begin{array}{l}6=\text { sangat setuju, } 5=\text { setuju, } 4=\text { cukup setuju, } 3= \\
\text { kurang setuju, } 2=\text { tidak setuju, } 1=\text { sangat tidak } \\
\text { setuju. }\end{array}$ \\
\hline 3 & Ruang kuliah bersih dan nyaman & $\begin{array}{l}6=\text { sangat setuju, } 5=\text { setuju, } 4=\text { cukup setuju, } 3= \\
\text { kurang setuju, } 2=\text { tidak setuju, } 1=\text { sangat tidak } \\
\text { setuju. }\end{array}$ \\
\hline 4 & $\begin{array}{l}\text { Tersedia fasilitas laboratorium komputer bagi } \\
\text { mahasiswa. }\end{array}$ & $\begin{array}{l}6=\text { sangat penting, } 5=\text { penting, } 4=\text { cukup penting, } \\
3=\text { kurang penting, } 2=\text { tidak penting, } 1=\text { sangat tidak } \\
\text { penting. }\end{array}$ \\
\hline 5 & $\begin{array}{l}\text { Buku-buku di perpustakaan tersedia sesuai } \\
\text { dengan kebutuhan kurikulum }\end{array}$ & $\begin{array}{l}6=\text { sangat setuju, } 5=\text { setuju, } 4=\text { cukup setuju, } 3= \\
\text { kurang setuju, } 2=\text { tidak setuju, } 1=\text { sangat tidak } \\
\text { setuju. }\end{array}$ \\
\hline 6 & $\begin{array}{l}\text { Tersedia ruang untuk diskusi dan untuk } \\
\text { kegiatan mahasisiwa }\end{array}$ & $\begin{array}{l}6=\text { sangat penting, } 5=\text { penting, } 4=\text { cukup penting, } \\
3=\text { kurang penting, } 2=\text { tidak penting, } 1=\text { sangat tidak } \\
\text { penting. }\end{array}$ \\
\hline 7 & $\begin{array}{l}\text { Dosen tepat waktu dalam memberikan } \\
\text { perkuliahan, baik masuk dan keluar kelas }\end{array}$ & $\begin{array}{l}6=\text { sangat setuju, } 5=\text { setuju, } 4=\text { cukup setuju, } 3= \\
\text { kurang setuju, } 2=\text { tidak setuju, } 1=\text { sangat tidak } \\
\text { setuju. }\end{array}$ \\
\hline 8 & $\begin{array}{l}\text { Program studi teknik industri terakreditasi } \\
\text { BAN-PT }\end{array}$ & $\begin{array}{l}6=\text { sangat penting, } 5=\text { penting, } 4=\text { cukup penting, } \\
3=\text { kurang penting, } 2=\text { tidak penting, } 1=\text { sangat tidak } \\
\text { penting. }\end{array}$ \\
\hline 9 & $\begin{array}{l}\text { Dosen memiliki jenjang pendidikan } \mathrm{S} 2 \text { dan } \\
\text { memiliki kompetensi di bidang ilmunya. }\end{array}$ & $\begin{array}{l}6=\text { sangat penting, } 5=\text { penting, } 4=\text { cukup penting, } \\
3=\text { kurang penting, } 2=\text { tidak penting, } 1=\text { sangat tidak } \\
\text { penting. }\end{array}$ \\
\hline 10 & $\begin{array}{l}\text { Dosen menyampaikan perkuliahan dengan } \\
\text { interaktif dan menarik }\end{array}$ & $\begin{array}{l}6=\text { sangat setuju, } 5=\text { setuju, } 4=\text { cukup setuju, } 3= \\
\text { kurang setuju, } 2=\text { tidak setuju, } 1=\text { sangat tidak } \\
\text { setuju. }\end{array}$ \\
\hline
\end{tabular}


11 Mahasiswa diberikan ruang untuk menyampaikan aspirasi terhadap pelayanan kampus

$6=$ sangat penting, $5=$ penting, $4=$ cukup penting, $3=$ kurang penting, $2=$ tidak penting, $1=$ sangat tidak penting.

12 Kartu Hasil Studi (KHS) dibagikan kepada $6=$ sangat setuju, $5=$ setuju, $4=$ cukup setuju, $3=$ mahasiswa sesuai waktu yang telah ditentukan

13 Dosen bersedia memberikan bahan ajar kurang setuju, $2=$ tidak setuju, $1=$ sangat tidak setuju.

\begin{tabular}{|c|c|c|}
\hline 13 & Dosen bersedia memberikan bahan ajar & $\begin{array}{l}6=\text { sangat penting, } 5=\text { penting, } 4=\text { cukup penting, } \\
3=\text { kurang penting, } 2=\text { tidak penting, } 1=\text { =sangat tidak } \\
\text { penting. }\end{array}$ \\
\hline 14 & $\begin{array}{l}\text { Dosen memperhatikan dan mendukung untuk } \\
\text { kesuksesan dan prestasi mahasiswa }\end{array}$ & $\begin{array}{l}6=\text { sangat penting, } 5=\text { penting, } 4=\text { cukup penting, } \\
3=\text { kurang penting, } 2=\text { tidak penting, } 1=\text { sangat tidak } \\
\text { penting. }\end{array}$ \\
\hline 15 & $\begin{array}{l}\text { Staff administrasi ramah dalam melayani } \\
\text { mahasiswa }\end{array}$ & $\begin{array}{l}6=\text { sangat ramah, } 5=\text { ramah, } 4=\text { cukup ramah, } \\
3=\text { kurang ramah, } 2=\text { tidak ramah, } 1=\text { sangat tidak } \\
\text { ramah. }\end{array}$ \\
\hline
\end{tabular}

\section{b. Kepuasan mahasiswa.}

Kepuasan mahasiswa merupakan suatu tanggapan atau respon yang diberikan mahasiswa setelah mendapatkan pelayanan dari kampus, yang diukur dengan menggunakan skor $(6=$ sangat puas, $5=$ puas, $4=$ cukup puas, $3=$ kurang puas, $2=$ tidak puas, $1=$ sangat tidak puas).

\section{Hipotesis dan Metode Analisis.}

a. Hipotesis

Hipotesis dari penelitian ini adalah: analisis kinerja kualitas pelayanan terhadap kepuasan mahasiswa.

\section{b. Metode Analisis}

Untuk menguji hipotesis yang telah diajukan, digunakan diagram Cartesius, yang dapat mengetahui tingkat kepentingan pelayanan menurut konsumen disbanding dengan tingkat kepuasan konsumen terhadap pelayanan yang diberikan oleh kampus. Diagram Cartesius dapat digambarkan sebagai berikut:

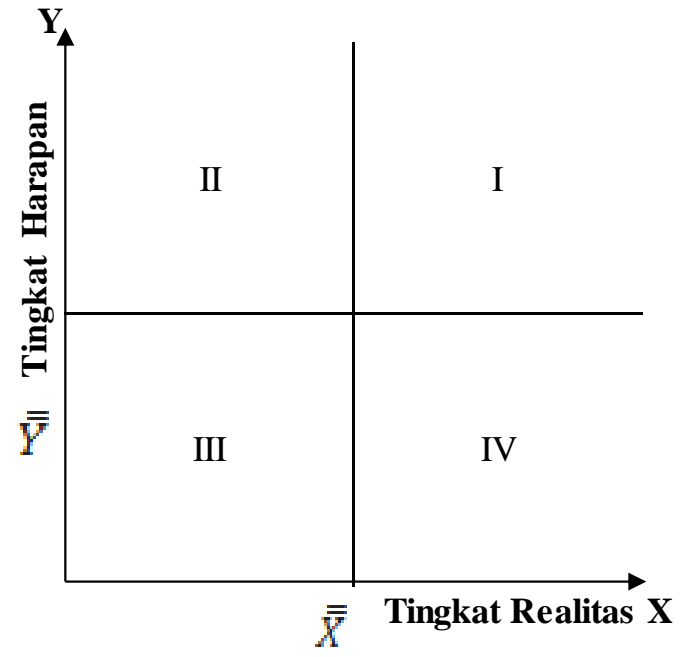

Gambar 2.1. Diagram Cartesius

Berikut adalah penjelasan dari masing-masing kuadran pada diagram cartesius berdasarkan Gambar 2.1.
- Kuadran I - Pertahankan prestasi (Keep up the good work) 
Atribut ini dianggap sangat penting oleh mahasiswa dan pelayanannya sangat memuaskan, sehingga institusi harus mempertahankan kualitas pelayanannya.

- Kuadran II - Prioritas utama (Concentrate Here)

Atribut ini dianggap sangat penting oleh mahasiswa tetapi pelayanannya tidak memuaskan, sehingga institusi harus meningkatkan kualitas pelayanan sehingga atribut tersebut diupayakan bisa bergeser dari kuadran II menuju kuadran I.
Atribut ini dianggap kurang atau tidak penting oleh mahasiswa dan pelayanannya kurang memuaskan.

- Kuadran IV - Berlebihan (Possible Overkill)

Atribut ini dianggap kurang atau tidak penting oleh mahasiswa tetapi pelayanannya sangat memuaskan

Adapun rumus yang dipergunakan untuk menghitung nilai-nilai tersebut adalah sebagai berikut:

- Kuadran III - Prioritas rendah (Low

Priority)

Rata - rata $(\bar{X}$ atau $\bar{Y})=\frac{\text { (Jumlah nilai jawaban masing-masing komponen })}{N}$

Rata - rata $(\overline{\bar{X}}$ atau $\overline{\bar{Y}})=\frac{\text { Jumlah Nilai Rata }- \text { rata }}{N}$

$\mathrm{N}=$ Jumlah responden

Keterangan:

$\mathrm{Y}=$ Tingkat kepuasan harapan mahasiswa

$\mathrm{X}=$ Tingkat Realitas yang dirasakan mahasiswa akan pelayanan yang diberikan oleh institusi.

$\bar{X}=$ Rata-rata tingkat kepuasan mahasiswa yang diperoleh dari rata-rata hasil hitungan tingkat kepuasan mahasiswa.

$\bar{Y}=$ Rata-rata tingkat harapan mahasiswa yang diperoleh dari rata-rata hasil hitungan tingkat harapan Mahasiswa

$\overline{\bar{X}}=$ Rata-rata kedua, yang diperoleh dari jumlah rata-rata tingkat realitas yang dirasakan mahasiswa dibagi dengan jumlah komponen yang berkaitan dengan pelayanan

$\overline{\bar{Y}}=$ Rata-rata kedua, yang diperoleh dari jumlah rata-rata tingkat harapan dibagi dengan jumlah komponen yang berkaitan dengan pelayanan

\section{c. Kriteria Hipotesis}

Jika hasil penelitian berada di kuadran III dan IV, maka pihakkampus bisa mengabaikan karena pelayanan tersebut bisa dianggap kurang atau tidak penting oleh konsumen.

\section{HASIL PENELITIAN}

Analisis yang digunakan dalam penelitian ini menggunakan diagram Cartesius yang dapat dipergunakan untuk mengetahui tingkat kepuasan kualitas pelayanan yang diterima oleh mahasiswa strata 1 (satu) Sekolah Tinggi Teknologi Mutu Tangerang

Dalam melakukan pengukuran tingkat harapan kepuasan mahasiswadibanding tingkat realitas kualitas pelayanan yang dirasakanmahasiswa, dilakukan dengan langkah-langkah sebagai berikut:

\section{Analisis kinerja kualitas pelayanan dan kepuasan mahasiswa}

Dari perhitungan dan pengolahan data hasil kuesioner yang terkumpul diperoleh hasil seperti tampak pada tabel 3.1.di bawah ini 
Tabel.3.1.

Rata-rata Hasil Kuesioner Kualitas Pelayanan Terhadap Mahasiswa

\begin{tabular}{clcc}
\hline Faktor & \multicolumn{1}{c}{ FAKTOR KEPUASAN } & $\overline{\boldsymbol{Y}}$ & $\overline{\boldsymbol{X}}$ \\
\hline 1 & LCD, AC dan Wifi berfungsi dengan baik & 5,82 & 4,56 \\
\hline 2 & Dosen dan karyawan berpenampilan baik dan rapih & 5,80 & 5,65 \\
\hline 3 & Ruang kuliah bersih dan nyaman. & 5,77 & 5,56 \\
\hline 4 & Tersedia fasilitas laboratorium komputer bagi mahasiswa & 4,95 & 3,93 \\
\hline 5 & $\begin{array}{l}\text { Buku-buku di perpustakaan tersedia sesuai dengan } \\
\text { kebutuhan kurikulum }\end{array}$ & 5,66 & 4,39 \\
\hline 6 & $\begin{array}{l}\text { Tersedia ruang untuk diskusi dan untuk kegiatan } \\
\text { mahasiswa. }\end{array}$ & 5,63 & 4,63 \\
\hline 7 & $\begin{array}{l}\text { Dosen tepat waktu dalam memberikan perkuliahan, baik } \\
\text { masuk dan keluar kelas }\end{array}$ & 5,75 & 4,72 \\
\hline 8 & Program studi teknik industri terakreditasi BAN-PT & 5,25 & 4,66 \\
\hline 9 & $\begin{array}{l}\text { Dosen memiliki jenjang pendidikan S2 dan memiliki } \\
\text { kompetensi di bidang ilmunya }\end{array}$ & 5,83 \\
\hline 10 & $\begin{array}{l}\text { Dosen menyampaikan perkuliahan dengan interaktif dan } \\
\text { menarik }\end{array}$ & 5,83 & 4,40 \\
\hline 11 & $\begin{array}{l}\text { Mahasiswa diberikan ruang utk menyampaikan aspirasi } \\
\text { terhadap pelayanan kampus. }\end{array}$ & 5,56 & 4,71 \\
\hline 12 & $\begin{array}{l}\text { Kartu Hasil Studi (KHS) dibagikan kepada mahasiswa } \\
\text { sesuai waktu yang telah ditentukan. }\end{array}$ & 5,76 & 3,97 \\
\hline 13 & Dosen bersedia memberikan bahan ajar. & 5,87 & 5,65 \\
\hline 14 & $\begin{array}{l}\text { Dosen memperhatikan dan mendukung untuk kesuksesan } \\
\text { dan prestasi mahasiswa. }\end{array}$ & 5,77 & 5,49 \\
\hline 15 & Staff administrasi ramah dalam melayani mahasiswa. \\
\hline
\end{tabular}

Langkah selanjutnya adalah yang diberikan oleh kampusdari 235 melakukan pengolahan data yang diambil mahasiswa aktif, dengan menggunakan dari 15 pertanyaan faktor kepuasan aplikasi SPSS dengan menggunakan mahasiswa dan hasil penilaian yang metode diagram cartesius, maka didapat berupa harapan dan realisasi kepuasan graph (grafik) seperti yang terlihat pada mahasiswa yang merupakan pelayanan gambar di bawah ini 3.1.

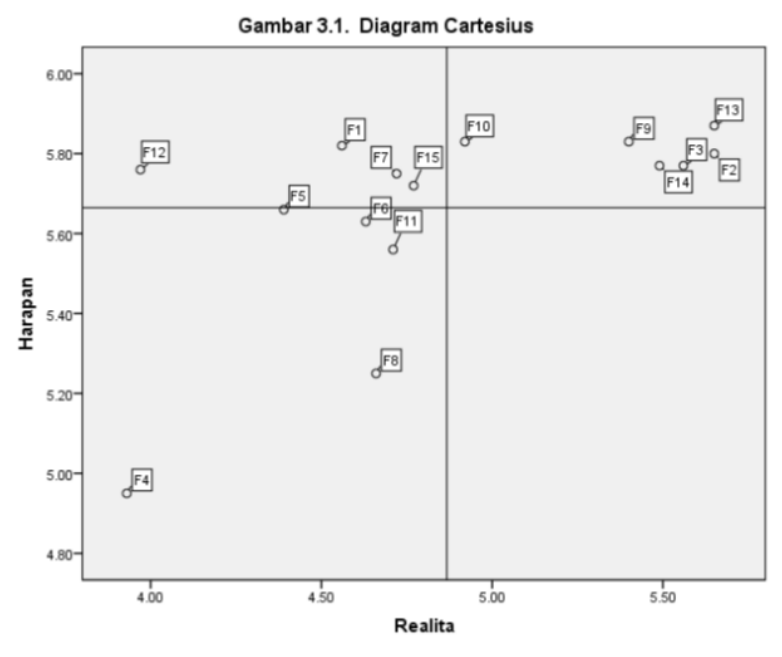


Analisis dengan menggunakan diagram Cartesian pada gambar 3.1. memperlihatkan bahwa setiap atribut terbagi didalam empat kuadran, penjelasannya adalah sebagai berikut:

Kuadran I.Faktor kepuasan yang berada pada kuadran I memiliki arti bahwa faktor kepuasan pada kuadran ini memuaskan dan dianggap penting oleh pelanggan, yang diantaranya bisa dilihat pada Tabel 3.2.

Tabel.3.2.

Faktor Kepuasan Pada Kuadran I

\begin{tabular}{clc}
\hline Faktor & \multicolumn{1}{c}{ Faktor kepuasan } & Ordinat \\
\hline $\mathbf{2}$ & Dosen dan karyawan berpenampilan baik dan rapih & $5,65,5,80$ \\
\hline $\mathbf{3}$ & Ruang kuliah bersih dan nyaman & $5.56,5,77$ \\
\hline $\mathbf{9}$ & $\begin{array}{l}\text { Dosen memiliki jenjang pendidikan S2 dan } \\
\text { memiliki kompetensi di bidang ilmunya }\end{array}$ & $5,40,5,83$ \\
\hline $\mathbf{1 0}$ & $\begin{array}{l}\text { Dosen menyampaikan perkuliahan dengan interaktif } \\
\text { dan menarik }\end{array}$ & $4,92,5,83$ \\
$\mathbf{1 3}$ & Dosen bersedia memberikan bahan ajar & $5,65,5,87$ \\
\hline $\mathbf{1 4}$ & $\begin{array}{l}\text { Dosen memperhatikan dan mendukung untuk } \\
\text { kesuksesan dan prestasi mahasiswa }\end{array}$ & $5,65,5,87$ \\
\hline
\end{tabular}

Kuadran II.Faktor kepuasan yang berada pada kuadran II memiliki arti bahwa faktor kepuasan pada kuadran ini kurang memuaskan dan dianggap penting oleh mahasiswa.yang diantaranya bisa $\begin{array}{llll}\text { dilihat pada } & \text { Tabel }\end{array}$

Tabel.3.3.

Faktor Kepuasan Pada Kuadran II

\begin{tabular}{clc}
\hline Faktor & \multicolumn{1}{c}{ Faktor kepuasan } & Ordinat \\
\hline $\mathbf{1}$ & FasilitasLCD, AC dan Wifi & $4,56,5,82$ \\
\hline $\mathbf{7}$ & Dosen tepat waktu dalam memberikan perkuliahan & $4,72,5,75$ \\
\hline $\mathbf{1 2}$ & $\begin{array}{l}\text { Kartu Hasil Studi (KHS) dibagikan kepada } \\
\text { mahasiswa sesuai waktu yang telah ditentukan. }\end{array}$ & $4,71,5,56$ \\
\hline $\mathbf{1 5}$ & Staf administrasi ramah dalam melayani mahasiswa & $4,77,5,72$ \\
\hline
\end{tabular}

Kuadran III.Faktor kepuasan yang berada pada kuadran III memiliki arti bahwa faktor kepuasan pada kuadran ini berada pada prioritas rendah karena tidak terlalu penting bagi mahasiswa.Hal ini terlihat dari rendahnya tingkat kepentingan dan tingkat kinerja perusahaan.yang bisa dilihat pada Tabel 3.4 .

Tabel.3.4.

Faktor Kepuasan Pada Kuadran III

\begin{tabular}{clc}
\hline Faktor & \multicolumn{1}{c}{ Faktor kepuasan } & Ordinat \\
\hline $\mathbf{4}$ & $\begin{array}{l}\text { Tersedia fasilitas laboratorium komputer bagi } \\
\text { mahasiswa }\end{array}$ & $3,93,4,95$ \\
\hline $\mathbf{5}$ & $\begin{array}{l}\text { Buku-buku di perpustakaan tersedia sesuai dengan } \\
\text { kebutuhan kurikulum }\end{array}$ & $4,39,5,66$ \\
\hline $\mathbf{6}$ & $\begin{array}{l}\text { Tersedia ruang untuk diskusi dan untuk kegiatan } \\
\text { mahasiswa }\end{array}$ & $4,63,5,63$ \\
\hline
\end{tabular}




\begin{tabular}{clc}
\hline Faktor & \multicolumn{1}{c}{ Faktor kepuasan } & Ordinat \\
\hline $\mathbf{8}$ & Program studi teknik industri terakreditasi BAN-PT & $4,66,5,25$ \\
\hline $\mathbf{1 1}$ & $\begin{array}{l}\text { Mahasiswa diberikan ruang utk menyampaikan } \\
\text { aspirasi terhadap pelayanan kampus }\end{array}$ & $4,71,5,56$ \\
\hline
\end{tabular}

Kuadran IV.Sebagai daerah yang cenderung berlebihan, karena dianggap kurang penting oleh mahsiswa, tetapi dijalankan sangat baik oleh perusahaan.Hal ini terlihat dari rendahnya tingkat kepentingan dan tingginya tingkat kinerja perusahaan. Hasil analisis survey kepuasan mahasiswa menunjukan tidak ada faktor kepuasan yang menempati posisi kuadran IV.

Dari analisis diatas akan lebih ideal jika faktor F1, F7, F12 dan F15 terletak di kuadran II bergeser menuju kuadran I, sehingga dapat memuaskan pelanggan. Oleh karena itu, institusi Sekolah Tinggi Teknologi Mutu Muhammadiyah perlu melakukan tindakan peningkatan kualitas pelayanan terhadap faktor faktor di bawah ini yang antara lainadalah:

1. F1 kepuasan pada pelayanan fasilitasLCD, AC dan WIFI ketidakpuasan mahasiswa pada akses WIFI kurang cepat dan kurang stabil serta tidak bisa diakses di setiap sudut ruangan;

2. Faktor Dosen tepat waktu dalam memberikan perkuliahan, baik masuk dan keluar kelas, ketidakpuasan mahasiswa dosen sering terlambat;

3. Faktor Kartu Hasil Studi (KHS) dibagikan kepada mahasiswa sesuai waktu yang telah ditentukan;

4. Faktor Staf administrasi ramah dalam melayani mahasiswa.

Meningkatkan kualitas pelayanan yang dianggap penting harus dilaksanakan secara maksimal hingga keinginan untuk memuaskan pelanggan dapat tercapai.

\section{KESIMPULAN}

Setelah dilakukan pengukuran, penilaian dan analisis secara kuantitatif dengan menggunakan diagram cartesius maka menunjukkan bahwa:

1. Faktor kepuasan pada kuadran I, yang bisa dilihat pada Tabel 3.2. Pelanggan merasa puas dan menganggap penting terhadap faktor kualitas pelayanan dan kinerja lembaga Sekolah Tinggi Teknologi Mutu Muhammadiyah. Maka setiap faktor kepuasan pada kuadran ini harus dipertahankan kinerjanya oleh lembaga, karena merupakan faktor penunjang kepuasan pelanggan. Hal ini dapat dilihat dari tingginya tingkat kepentingan dan tingkat kinerja lembaga Sekolah Tinggi Teknologi Mutu Muhammadiyah;

2. Faktor kepuasan pada kuadran II, yang bisa dilihat pada Tabel 3.3. yaitu pelanggan merasa tidak puas, dan menganggap penting terhadap faktor kualitas pelayanan ini, kinerja kualitas pelayanan lembaga pada kuadran ini harus ditingkatkan, karena kinerja kualitas pelayanan dalam kuadran ini belum dijalankan dengan baik oleh lembaga;

3. Faktor kepuasan pada kuadran III, yang bisa dilihat pada Tabel 3.4. menunjukan bahwa pelanggan merasa tidak puas dan menganggap tidak penting terhadap faktor kualitas pelayanan ini, Faktor kepuasan berada pada prioritas rendah karena tidak terlalu penting bagi pelanggan. 


\section{DAFTAR PUSTAKA}

Azwar, S. (2010). Reliabilitas dan Validitas; Yogyakarta: Pustaka Pelajar.

Abdullah, T., \& Tantri, F. (2015).Manajemen Pemasaran; Jakarta; Rajawali Pers.

Firdaus, M. A., \& Yudhawati, D. (2018).Mengukur Kepuasan Mahasiswa Dengan IPA. Inovator, 7(1), 69-89.

Hadiati, S., Ruci, S,.(1999) Analisis Kinerja Kualitas Pelayanan Terhadap Kepuasan Pelanggan pada Telkomsel Malang Area.

Harijanto, B., \& Ariyanto, Y. (2017).Sistem Informasi Pengukuran Kepuasan Pelanggan (Studi Kasus Politeknik Negeri Malang). JURNAL ELTEK, 12(2), 42-52.

John, A. Goodman. (2009). Strategic Customer Service, American Management Association; AMACOM.

Kotler, P. (2000). Manajemen Pemasaran Indonesia, Alih Bahasa oleh Ancella Anitawati dan Hermawan, Edisi Pertama, Jakarta: Salemba Empat.

Kotler, Philip dkk. 2002. Manajemen Pemasaran Edisi Milenium. Jakarta: PT. Prenhallindo.

1ldikti12.ristekdikti.go.id (2019).Akreditasi Perguruan Tinggi, Jakarta; Badan Akreditasi Nasional Perguruan Tinggi.

Mulyawan, R. (2016). Birokrasi Dan Pelayanan Publik; Bandung; UNPAD Press.

Narbuko, C. dan Achmadi, A. (2018) Metodologi Penelitian: Jakarta: Bumi Aksara.
Sujarweni, W. (2015). SPSS Untuk Penelitian; Yogyakarta: Pustaka Bare Press.

Sulastri, T. (2016).Analisis Kepuasan Mahasiswa Terhadap Kinerja Dosen. Optimal: Jurnal Fakultas Ekonomi Universitas Islam" 45" Bekasi, 10(2), 154569.

Sukmanasa, E., Novita, L., \& Siti, F. (2017).Analisis Kepuasan Mahasiswa terhadap Kinerja Dosen Program Studi Pendidikan Guru Sekolah Dasar Universitas Pakuan. Pedagonal: Jurnal Ilmiah Pendidikan, 1(2), 91-99.

Syaifullah, S., Wijaya, I. G. P. S., \& Husodo, A. Y. (2018).Sistem Informasi Kepuasan Layanan Administrasi Akademik Berbasis IPA (Importance Performance Analysis) Studi Kasus Fakultas Teknik Universitas Mataram. Journal of Computer Science and Informatics Engineering (J-Cosine), 2(1).

Tjiptono, F. dan Diana, A. (2014).Total Quality Management, Konsep Total Quality Management; Yogyakarta: Andi.

Tjiptono, F. dan Chandra, G. (2016).Service, Quality dan Satisfaction; Yogyakarta: Andi.

Tukiran, M. (2016) Membangun Sistem Manajemen Mutu Berdasarkan ISO 9001:2015: LeutikaPrio: Yogyakarta.

Winata, A., Nuansyah, B., \& Alfian, F. Y. (2017).Analisis Tingkat Kepuasan Mahasiswa Terhadap Sistem Informasi Keuangan Dan Akademik (SISKA) IIB Darmajaya. Jurnal Manajemen Magister Darmajaya, 3(01), 1-16. 